\section{KODAIKANAL OBSERVATORY}

\section{ANNUAL REPORTS FOR 1951 AND 1952}

$\mathrm{T}$

HE annual reports of the Kodaikanal Observ. atory for the years 1951 and 1952*, both of which have only recently been received, deal mainly with the astronomical work of the Observatory ; the meteorological data appear in the India Weather Review and the administrative details are to be incorporated in the annual report of the India Meteorological Department. The golden jubilee of the Observatory was celebrated in September 1951, and the event was marked by the inauguration of the newly built Ionospheric Laboratory and of the newly installed 'Bhavnagar Telescope', a 20-in. Cassegrain reflector constructed by Grubb which originally belonged to the now defunct Poona Observatory and named after Maharajah Takhtasinghji of Bhavnagar.

An expedition was organized to observe the total eclipse of the sun on February 25, 1952, and the party of four, led by Dr. A. K. Das, started on December 27, 1951, for the eclipse camp at Ar Ratawi in Iraq. On this expedition, which is referred to in the 1952 report, the observational programme was unfortunately frustrated by bad weather at the time of the eclipse.

International co-operation, including the exchange of spectroheliograms and photoheliograms with foreign observatories, was maintained as usual (a list of these observatories is given); and the daily broadcasts of 'ursigrammes' relating to solar activity, and to issuing warnings for expected ionospheric and geomagnetic disturbances whenever expected, were continued.

A list of the equipment of the Observatory is given in each report, including $(a)$ astronomical and spectroscopic instruments, (b) magnetic instruments, (c) electronic instruments, $(d)$ workshop machinery, and $(e)$ other instruments, with the names of the different instruments in use. The 1952 list shows one more under $(a)$, one more under $(b)$ and six more under $(c)$ compared with the 1951 list. Weather conditions during 1951 were better than those of the previous year, and those of 1952 were better than the 1951 conditions. There was a considerable decrease in sunspot activity in both years. The number of prominences in 1951 showed a decrease of 15 per cent compared with the number in 1950, but there was an increase in the areas of 7 per cent; this was due to greater prominence activity during the second half of 1951. In 1952, prominence activity as represented by areas showed a decrease of 16 per cent, and the numbers an increase of 23 per cent over the 1951 results.

* Kodaikanal Observatory. Annual Report for the Year 1951; pp. 12, 1953 ; As. 12 or $1 s$. (Delhi : Manager of Publications.)

\section{PREHISTORIC SETTLEMENT PATTERNS IN THE VIRÚ VALLEY, PERU}

$\mathrm{T}$

HE Virú Valley Project was an intensive survey of one of the smaller irrigated valleys of the Peruvian coast. It was mainly archæological, but embraced also cultural geography and a study of the modern population, and it was carried out by a number of teams from different North American institutions with the co-operation of Peruvian scholars. Each institution supported its own team and is publishing the results, but they worked together and shared certain resources supplied by the Viking Fund of Now York. The work was done in 1946, when Prof. G. R. Willey was working for the Bureau of American Ethnology. Although publication has been long delayed, some of Prof. Willey's views have influenced publication by his colleagues, so they have not been altogether hidden from students of the subject. Now that his conclusions are published in full as a Bulletin of the Bureau of American Ethnology*, his work forms an exceedingly valuable and interesting contribution to archæology.

The work is based on what must have been a very strenuous survey of the visible settlement sites in the valley, and descriptions of them, with plans, form a large part of the book. Each of the descriptive sections begins with a summary of the contents, so that the bulk of them need be used for reference only. They are preceded by introductory chapters which define the problem and describe the valley, and are followed first by a summary with conclusions about the actual settlement patterns, and then by a discussion of what can be learned from them about the population and its organization at different stages. Finally, these data are related to what is known of Peru as a whole. The plates, grouped at the end, are a useful addition, but the reproduction of some of them is a trifle 'woolly'.

Among the several useful publications resulting from the Virú Valley Project, this deserves a prominent place. By his fresh and thoughtful approach to his subject, Prof. Willey has made a notable contribution to our understanding of the ancient peoples of Peru. The organizers of the Project were fortunate in being able to select a unit of manageable size to deal with, and one which was sufficiently self-contained to make it possible to observe the effects of outside influences and invasions. Very useful results might be obtained if it were possible to follow their example in other centres of ancient civilization.

G. H. S. Bushnell

* Smithsonian Institution. Bureau of American Ethnology, Bulletin 155:- Prehfstoric Settlement Patterns in the Virú Valley, Peru. By Printing Office, 1953.) 4 dollars.

\section{PHOTOLYSIS OF POLY METHYL VINYL KETONE: FORMATION OF BLOCK POLYMERS}

By J. E. GUILLET and Prof. R. G. W. NORRISH, F.R.S.

Department of Physical Chemistry, University of Cambridge

$\mathrm{T}$ HE primary photolysis of aliphatic ketones, both in the gas phase and in solution, has been shown to occur by two simultaneous reactions ${ }^{2}$ :

Type I, in which two free radicals are formed:

$$
R . \mathrm{CO} . R^{\prime} \stackrel{h v}{\rightarrow} R .+R^{\prime} \mathrm{CO} . \rightarrow R .+R^{\prime} .+\mathrm{CO}
$$

Type II, in which the molecules can split in the $\alpha-\beta$ position to the carbonyl group to give an olefin and a lower ketone, without the formation of free radicals; for example :

$$
R \mathrm{CH}_{2} \mathrm{CH}_{2} \mathrm{CH}_{2} \mathrm{COR}^{\prime} \stackrel{h v}{\rightarrow} R \mathrm{CH}: \mathrm{CH}_{2}+\mathrm{CH}_{3} \mathrm{COR}^{\prime}
$$

